\title{
"I'd rather be dead than disabled"- the ableist conflation and the meanings of disability
}

\section{Joel Michael Reynolds}

To cite this article: Joel Michael Reynolds (2017) "l'd rather be dead than disabled"-the ableist conflation and the meanings of disability, Review of Communication, 17:3, 149-163, DOI: 10.1080/15358593.2017.1331255

To link to this article: http://dx.doi.org/10.1080/15358593.2017.1331255

册Published online: 16 Jun 2017.

Submit your article to this journal

Џ Article views: 63

Q View related articles $\sqsubset$

View Crossmark data $₫$ 


\title{
"I'd rather be dead than disabled"- the ableist conflation and the meanings of disability
}

\author{
Joel Michael Reynolds (i)* \\ Department of Philosophy, Emory University, Atlanta, GA, U.S.A.
}

\begin{abstract}
Despite being assailed for decades by disability activists and disability studies scholars spanning the humanities and social sciences, the medical model of disability-which conceptualizes disability as an individual tragedy or misfortune due to genetic or environmental insult-still today structures many cases of patient-practitioner communication. Synthesizing and recasting work done across critical disability studies and philosophy of disability, I argue that the reason the medical model of disability remains so gallingly entrenched is due to what I call the "ableist conflation" of disability with pain and suffering. In an effort to better equip healthcare practitioners and those invested in health communication to challenge disability stigma, discrimination, and oppression, I lay out the logic of the ableist conflation and interrogate examples of its use. I argue that insofar as the semiosis of pain and suffering is structured by the lived experience of unwelcome bodily transition or variation, experiences of pain inform the ableist conflation by preemptively tying such variability and its attendant disequilibrium to disability. I conclude by discussing how philosophy of disability and critical disability studies might better inform health communication concerning disability, offering a number of conceptual distinctions toward that end.
\end{abstract}

\section{ARTICLE HISTORY}

Received 17 May 2016

Accepted 17 March 2017

\section{KEYWORDS}

Philosophy of disability; health communication; medical humanities; ableism; pain; Martin Heidegger

For it would be better to die once and for all than to suffer pain for all one's life.

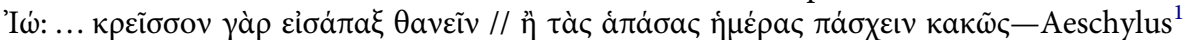

Our aversion to the very idea of being disabled forestalls our understanding the disabled from their perspective.-Anita Silvers ${ }^{2}$

Although we awake to life in profound bodily dependency, although we live out our bodies in a permanent state of vulnerability and variability, and although through age, if nothing else, we return to originary states of dependency, we have come to fear bodily change. ${ }^{3}$ That is to say, we are often averse to, if not fearful of, uncontrolled, unexpected, and unwelcomed bodily transitions. Modern medicine acts as a therapy for the soul by taking this fear at face value and mitigating it through genetic intervention, surgical repair, and myriad forms of prevention and care. Health communication reveals volumes about such worries and fears over the body's fluid nature, the numerous 
effects of which we have only recently in English come to categorize as "disabilities." But do we really know what this term means? And are the fears to which some attach it justified? Are they grounded in the experiences they purport to be about? Does not one's interpretation of the meaning of "disability" hold enormous sway over how one experiences one's body, its transformations, and the choices one makes about it? Does not that interpretation alter, amplify, or even erase fears that can drive medical decisionmaking and the ease or difficulty of communication about it? What if a vast range of medical thinking and communication about disability is based not in its lived experience, but in misguided aversion to and fear of it?

Despite being assailed for decades by disability activists and disability studies scholars spanning the humanities and social sciences, the medical model of disability still today structures too many cases of patient-practitioner communication. ${ }^{4}$ This model conceptualizes disability as an individual tragedy or misfortune due to genetic or environmental insult. Tellingly, the incorporation of disability education into medical training is itself a point of contestation. This is especially true with regard to scholarship in critical disability studies, which both begins from a critique of the medical model of disability and also interrogates multiple theoretic presumptions in medicine more generally. ${ }^{5}$ Unsurprisingly, people with disabilities report significantly higher inadequacies in patient-practitioner communication. ${ }^{6}$ A contributing factor to this situation is the relative lack of engagement between critical disability studies and health communication studies, and the overarching aim of this article is to demonstrate the ways in which the former might enrich the latter.

Synthesizing and recasting work done across critical disability studies and philosophy of disability, I argue that the reason the medical model of disability remains so gallingly entrenched is because of what I call the "ableist conflation": the conflation of disability with pain and suffering. ${ }^{7}$ On this logic, disability is both a sign and cause of existential dis-ease and dis-order. In an effort to better equip healthcare practitioners and all those invested in health communication to challenge disability stigma, discrimination, and oppression, I first lay out the logic of the ableist conflation and interrogate examples of its use. ${ }^{8}$ I argue that insofar as the semiosis of pain and suffering is structured by the lived experience of unwelcome bodily transition or variation, experiences of pain inform the ableist conflation by preemptively tying such variability and its attendant existential disequilibrium to disability. I conclude by discussing how philosophy of disability and critical disability studies might better inform health communication concerning disability, and I offer a number of conceptual distinctions toward that end, especially as they might combat the ableist conflation and disability stigma.

\section{Health communication and disability}

Health communication scholarship has addressed multiple issues related to communication and narration about disability. This research includes studies on the manner in which medical students communicate with and about people with disabilities; ${ }^{9}$ how such communication occurs within families; ${ }^{10}$ how perceptions about disability affect medical decision-making; ${ }^{11}$ and how assumptions about disability inform health communication and medical education as a whole. ${ }^{12}$ From a broader philosophy of disability lens, it becomes clear that much of this research revolves around navigating-or failing to navigate - the multiple meanings of disability. What do I mean by this? 
The term "disability" picks out an extremely complex set of phenomena. Given its complexity, there are debates over nearly every aspect of its meaning. For example, is disability a natural kind-does it refer to a real set of characteristics or traits of people or other things in the world ${ }^{13}$ If disability is instead a way or mode of being, "what sort of being is it?" 14 Does "disability" refer to an intrinsically positive, negative, or neutral experience or set of experiences? ${ }^{15}$ Is "disability" in fact more a social than individual phenomenon? ${ }^{16}$ If so, with respect to all or only some forms of disability? How do intellectual as opposed to physical disabilities alter the lived experience and potential meanings of disability? ${ }^{17}$ How have misguided assumptions about disability and intellectual disability in particular restricted political rights? ${ }^{18}$ Does disability name a minority identity? ${ }^{19}$ Is disability political, and if so, in what ways? ${ }^{20}$ How is one to understand and communicate about invisible disabilities, especially given disability's shifting, situated, and diverse global politics? ${ }^{21}$ How is chronic pain or illness different from what we think of as disability? ${ }^{22}$ How is the historical oppression of people with disabilities related to understandings and governance of sexual activity? ${ }^{23}$ How have people with disabilities been disproportionately surveilled and monitored? ${ }^{24}$ How do questions about disability intersect with those of gender and sexuality $?^{25}$ With race $?^{26}$ With education? ${ }^{27}$ With class? ${ }^{28}$ With the predominance of cultural and institutional ableism? ${ }^{29}$ How do some with disabilities pass as ablebodied or neurotypical? ${ }^{30}$ How widely has the meaning and conceptualization of disability changed over history and across cultures? ${ }^{31}$ How have varying historical perceptions of disability become determinate for the meaning of lives defined by it today? ${ }^{32}$ And what does such historical variance teach us?

How one responds to these questions will fundamentally shape how one communicates about disability. Ultimately, it will affect how one thinks about and treats others, including oneself. Put bluntly, a medical practitioner who uncritically conceptualizes disability will actively, albeit likely unwittingly, contribute to disability stigma and to the epistemic and practical injustices that people with disabilities have historically and still face today. ${ }^{33}$ Take as an example the article, "How Do I Ask About Your Disability?" The authors frame the import of their study by noting that "individuals with disabilities have greater needs for patient-informed health care, yet describe health care professionals making erroneous assumptions about their goals, aspirations, and abilities, which impact both communication and treatment." 34 Yet, a version of the widely disparaged medical model of disability is deployed uncritically throughout, and there is no substantive engagement with the numerous meanings of disability detailed above. ${ }^{35}$ Because the very conceptualization of disability in the article is itself problematic, the improvements in interpersonal communication a practitioner might achieve through the study are marginal at best. In short, without a critical analysis of disability, one will likely end up unintentionally conceptualizing disability on faulty grounds, ultimately contributing to rather than countering or mediating disability stigma.

This is one reason why a critical disability studies approach has the potential to significantly enrich health communication studies: it provides practitioners with a more substantive understanding of the ways in which they can undo and actively resist unjust epistemic and material practices. I will now turn to assail one of the main conceptual errors in health communication about disability: the ableist conflation of disability with pain and suffering. 


\section{The ableist conflation}

Wherever operative, the ableist conflation flattens communication about disability to communication about pain, suffering, hardship, disadvantage, morbidity, and mortality. For example, in a 2015 Boston Globe op-ed, Steven Pinker proclaims,

Some say that it's simple prudence to pause and consider the long-term implications of [biomedical] research before it rushes headlong into changing the human condition. But this is an illusion ... slowing down research has a massive human cost. Even a one-year delay in implementing an effective treatment could spell death, suffering, or disability for millions of people. ${ }^{36}$

Setting aside the question-begging nature of this argument, Pinker finds that death, suffering, and disability are so similar that they can be listed together as experiences no one wants and obviously so. Imagine making sense of one's life when one is labeled "disabled" under such circumstances. Imagine the limitations thereby placed upon communication about it from the outset. Insofar as Pinker paints his argument in the veneer of common sense, a person living with a disability who disagrees with the aspiration of "eliminating disability" begins on the defensive about their experience of their own life.

Pinker's understanding is in step with the majority of transhumanists and posthumanists. Thinkers and activists who claim that title typically seek the total eradication of "disability" from the human species as a central goal. ${ }^{37}$ Yet they rarely, if ever, critically reflect upon their use of that term, not to mention the copious literatures that engage it, whether through reflective or empirical research. Trans- and posthumanists, like Pinker, conflate a whole range of corporeal variabilities categorized as "disabilities" not only with pain and suffering, but with disease, illness, and death. To be fair, Pinker does not explicitly claim in the quote above that disability is in and of itself a type of suffering. Yet, the rhetorical force of his series "death, suffering, or disability" could not be clearer: these phenomena are similar in that no one desires to experience them. Pinker capitalizes on this assumed homogenization to further the putative urgency in responding to their "threat" to progress. ${ }^{38}$

In another section from the same piece, he writes,

Have you had a friend or relative who died prematurely or endured years of suffering from a physical or psychiatric disease, such as cancer, heart disease, Alzheimer's, Huntington's, Parkinson's, or schizophrenia? Of course you have: the cost of disease is felt by every living human. The Global Burden of Disease Project has tried to quantify it by estimating the number of years lost to premature death or compromised by disability. In 2010 it was 2.5 billion, which means that about a third of potential human life and flourishing goes to waste. The toll from crime, wars, and genocides does not come anywhere close. ${ }^{39}$

Unlike the grammatical ambiguity of the former quote, disease, disability, and (premature) death are here treated interchangeably. Disability is rhetorically paralleled with death, crime, war, and genocide. Disability, as Pinker understands it, is a form of constitutive pain and suffering. He not only commits the ableist conflation but then employs its logic to argue against ethical reflection that would halt or slow the future of biomedical technologies. Worry about risk on your own time, Pinker seems to imply, because our global society must immediately continue reducing disability, disease, and death. Here, the force of the ableist conflation to foreclose the meanings of disability-and, ultimately, the meaning of being human as such-is on full display. It is this bold-faced linking of 
disability with pain, of which death is ultimately a species, that achieves such a spectacle of uncritical thinking about disability.

How, then, would one learn to decouple disability from pain and suffering? ${ }^{40}$ How might a medical practitioner-whether working in triage or palliative care, oncology or obstetrics-work against the disability stigma Pinker displays and the ableist conflation undergirding it? How can practitioners identify, interpret, and contest their own ableism and that of their patients in a way that engenders contestation of the historical discrimination and devaluation experienced by people with disabilities? How, in short, can communication between practitioners and patients better support justice for people with disabilities? As I explain in more detail below, insofar as humans widely identify and conceptualize pain and suffering as experiences to be avoided, phenomena that bring about pain and suffering are normatively disparaged - they are understood as negative. The social ostracization of those who seek out pain is one example of this. ${ }^{41}$ There is, however, a large literature across multiple humanistic and social scientific fields that demonstrate the many errors of associating disability with pain, suffering, and disadvantage. ${ }^{42}$ Understanding and working against the logic of the ableist conflation, I believe, is a necessary (though not thereby sufficient) step in improving practitioner-patient communication concerning disability, as well as communication about disability in general.

Although it can take many forms, I will suggest that the ableist conflation involves at least the following four claims:

(1) Disability is conceptualized as a lack or deprivation of a natural good.

(2) Deprivation of potential natural goods is considered a harm.

(3) Harm is understood to cause or be a form of pain and suffering.

(4) Given 1-3, disability is coextensive with (weak version) or causes (strong version) pain and suffering (linked with or even leading to death). ${ }^{43}$

This is the basic formula, I contend, that best explains the continued entrenchment of the medical model of disability and what could be called "medical intuitions" about disability. This is the formula that best explains disability's widespread cultural disparagement, from inspiration porn to disability hate crimes. ${ }^{44}$ This is the formula that best explains the basic logic of "I'd rather be dead than disabled." ${ }^{45}$ Note that given 1-4 disability evokes a similar response of negativity and urgency of intervention, and one would expect a person conceptually imbued with the ableist conflation to communicate about them in similar ways. ${ }^{46}$ People say, "I'm so sorry," to someone in pain, just as those without disability education do to many with disabilities - and often regardless of whether or not the person is visibly in pain at all. People often valorize and take inspiration from those who overcome pain, just as those without disability education do when enjoying and propagating inspiration porn. ${ }^{47}$ The countervailing logics of pity and inspiration make perfect sense if grounded in the ableist conflation.

To address all of the philosophical questions that the terms and formulations of the ableist conflation raises is impossible here. My aim is only to suggest that something like these sets of ideas and assumptions inform ableist intuitions and function as a disturbingly resilient habit of ableist thinking. The ableist conflation functions in part through capitalizing upon the ambiguity of its terms; it grips common sense by leaving the meaning of disability, harm, pain, and suffering all uncritically underdefined. 
I would further argue that there are assumptions and inferences based in the ableist conflation that are more pernicious than others, specifically the ones that engage in eugenic discourse. One could imagine a set of working assumptions that underwrite a eugenic form of the ableist conflation as follows:

(1) Disability is considered a lack or deprivation of a (natural) good.

(2) Deprivation of potential goods is considered a harm. ${ }^{48}$

(3) Harm is understood to cause or be a form of pain and suffering.

(A) The aim of politics and ethics is to maximize flourishing, in part by reducing harms and ameliorating pain and suffering.

(4) Disability causes or is concomitant with pain and suffering (given 1-3).

(A) Individuals and the state are justified in ending or otherwise curtailing the lives of people with disabilities in certain cases (given 1-4).

The infamous conclusion of the United States' 1927 Buck v. Bell case put this eugenic form of the ableist conflation quite clearly:

The public welfare may call upon the best citizens for their lives. It would be strange if it could not call upon those who already sap the strength of the State for these lesser sacrifices ... in order to prevent our being swamped with incompetence. It is better for all the world, if ... society can prevent those who are manifestly unfit from continuing their kind.... Three generations of imbeciles are enough. ${ }^{49}$

To maximize flourishing (including that of the State as a body), the State can forcibly call upon the "unfit" to not reproduce because doing so would constitute a harm against the State. For Justice Oliver Wendell Holmes Jr., certain forms of disability not only trump liberal egalitarianism but call upon a liberal society to end their genetic future. A most illiberal inference, indeed. ${ }^{50}$

With the hope of better understanding why disability might have ever become linked with pain and suffering in the first place, I will now turn to a discussion of how the reinforcement of the ableist conflation is structured by the lived experience of pain.

\section{The semiosis of pain}

Inquiries concerning pain run into an initial aporia. The pain of torture, the pain of unrequited love, or the pain of a life lived with chronic pain-are these not qualitatively similar only at the most abstract level, if at all? Could not only "reasoning from another world," to borrow Fyodor Dostoevsky's acerbic phrase, produce similarity across such disparate cases ${ }^{51}$ As tempting as this claim may be, I will argue that the laxity of language alone cannot account for the intricate semantic orchestration arranged by the polyphony of phenomena we describe with the term "pain."

For example, note the strikingly wide definition of pain given by the International Association for the Study of Pain (IASP):

an unpleasant sensory and emotional experience associated with actual or potential tissue damage, or described in terms of such damage.... It is unquestionably a sensation in a part or parts of the body, but it is also always unpleasant and therefore also an emotional experience. Experiences which resemble pain but are not unpleasant, e.g., pricking, should not be called pain. ${ }^{52}$ 
Part of the complexity of the definition is due to the fact that even in solely biological or neurophysiological terms, it is difficult to determine with substantive precision what does and does not qualify as pain. ${ }^{53}$ Arguably, the semantic and semiotic problem with pain is not simply a quirk or mistake of language, but reflects the fact that the experience of pain itself is profoundly ambiguous and diffuse.

David Sinclair notes,

The pain spots in the skin are so densely distributed that it is almost impossible to find a touch, cold, or warm spot which is not also sensitive to pain. Again, pain is unique in that it can be produced by almost any kind of stimulus, provided it is intense enough. ... Sometimes pain behaves as if the pure sensation were the dominant factor [and other times] the "affective component." 54

The definition from the IASP and the commentary by Sinclair might lead one to be suspicious of a universal definition of pain, much less a rigorous definition. I wish to focus here less on the meaning of pain and more on the way in which it comes to have a meaning associated with disability experience: by focusing one's attentional field on one's body.

The underlying logic of medical diagnosis is based upon semiotics: symptoms are understood as signs that refer to physical or psychological causes. ${ }^{55}$ Thus, diagnosis necessarily relies in part upon semiosis: the process whereby an object functions as a sign. ${ }^{56}$ In order to understand how disability might become conflated with pain and suffering, I contend, one must first achieve clarity concerning the semiosis of pain, on how pain comes to have a meaning affiliated negatively and suspiciously with disability. To answer this, I will turn to semiotics. For Charles Sanders Peirce, one of the foundational figures in the field of semiotics, there are three basic components of the semiotic process: the sign, the object, and the interpretant:

A sign, or representamen [a thing that represents], is something which stands to somebody for something in some respect or capacity. It addresses somebody, that is, creates in the mind of that person an equivalent sign, or perhaps a more developed sign. That sign which it creates I call the interpretant of the first sign. The sign stands for something, its object. ${ }^{57}$

What is crucial for Peirce is that the triadic relation between sign, object, and interpretant is "genuine," that is, in no way composed of dyadic relations. No piece can be thought without the other two pieces. What is more, each triad is constitutively chained or linked to an infinite set of other triadic possibilities. That is to say, any given sign can become an object of a different sign (thus constituting a different triad) just as any given interpretant can become a sign or object in some other triad. Meaning arises not through direct, unmediated relations of experience and language, but through the ongoing, ambiguous interplay of a multiplicity of discursive practices. This suggests that how we conceive and communicate about things is far more malleable than we might expect.

The key to a semiotic act for Peirce revolves around the question of reference, which is to say, the question of showing or indicating - a sign is something that stands to somebody for something. ${ }^{58}$ The essence of a sign, then, is its deictic or indicational character. Unlike Peirce, in Martin Heidegger's early existential semiotics, while the indicational character of the semiotic act is important, he places greater emphasis on the set of relations out of which and in which such a relationship could arise in the first place. ${ }^{59}$ For Heidegger, 
semiosis always involves one's entire world, the totality of references in and out of which one finds things meaningful. It is through this totality that the singular meaning of a given experience emerges.

Furthermore, a sign is always understood more specifically in terms of its usefulness - for some particular goal or end-signs orient us in the world. The signpost, for example, relates to a certain place or direction in a context; it orients one to that specific place and not another. If pain is like a signpost-a signal to somethingthen to what is it pointing? When the phenomenon of pain is broadened from a purely biomedical and clinical context, its meaning ranges over any situation wherein one is led to heed one's body. Insofar as experiences of pain are uncontrolled and unwelcome, pain has become a sign of being made into an object, being forced to take oneself as an object, and even forced from the possibility of subjective reflection, as in cases of extreme pain. Pain is thus limitrophic; it operates at the borders, the edges, of our being. It is, as Andrew Mitchell puts it, a "wound of relation." 60 Pain is a sign that we are beholden to the world to the point of death. Accordingly, as a sign that reveals the depth and character of the ephemerality of one's being-in-theworld, pain is the ultimate sign of mortality.

It is at this point that one can see why tying the meaning of disability to that of pain is so damning for all those with disabilities. Insofar as one fears death, one has good and profoundly motivating reasons to fear and avoid pain precisely in light of the stakes of its semiosis. If one then conflates experiences of disability with pain and thereby mortality, then it is no wonder that people say and think, "I'd rather be dead than disabled."61 It is in large part due to the ableist conflation that people with disabilities experience such stigma, disparagement, and misunderstanding-to the point that they are entirely left out of models of flourishing. As I hope to have already shown, disability is, upon critical reflection, neither a species of pain, nor suffering, nor is it coextensive with either. Disability does not necessarily reveal one's mortality. Disability reveals corporeal variability. Disability reveals the mutability and flexibility of life's effulgence.

Corporeal variability needs to be renarrated to contrast the dominant assumptions of the ableist conflation. Experiences of disability attest to a wide and positive range of meaning-making. For example, those in Deaf culture-who understand the experience of deafness not as audiological loss, but as a cultural identity based in practices of signing - find no ontological wounding at all in their experience of disability. ${ }^{62}$ Some born with nonphenotypical limb formations would say the same-nothing about their "disability" signifies a wound of relation, except insofar as societal factors contribute to their mistreatment or lack of equal access to social goods. It is a mistake to think that social inequities are inevitable and anchor one to a life of pain, suffering, and death.

Pain is a normative guillotine. ${ }^{63}$ Following Heidegger, the semiotic conflation of disability is a worlded phenomenon. That is to say, if the semiosis of pain is taken to indicate the possibility of the collapse of meaning and life through death, then any phenomenon linked to pain will be conceptualized as to-be-avoided. When disability is linked to pain through the ableist conflation, the death knell is sounded for understanding disability in the actual, wide, and variable range that induces its many positive, expected, and gainful forms as it expresses the variable constitution of the rhizomatic course of a human life well lived. 


\section{Dismantling the ableist conflation}

Susan Wendell has argued, both in her seminal work The Rejected Body and in later pieces, that disability studies needs to take more account of the stigmas and oppressions faced by those with chronic illness and/or chronic pain-the so-called "unhealthy disabled" who do not represent "the paradigmatic person with a disability who is healthy disabled and permanently and predictably impaired." 64 One could, at this point, still be unconvinced. Isn't cystic fibrosis very difficult to deal with? What about "mental illnesses," like schizophrenia, whose lived experienced is articulated in terms of suffering? ${ }^{65}$ The still unconvinced might say: Wouldn't one rather walk than not? Wouldn't one rather talk than not? To name the ableist conflation of disability with pain and suffering as an error of thinking is not to say that there are no cases of disability that are concomitant with experiences of pain and suffering. On the contrary, there are longstanding and ongoing debates within disability studies and philosophy of disability about the meaning, import, and turbulent politics of distinguishing between unhealthy disability and healthy disability.

Yet, the epistemic work involved in making such a distinction, I think, is a crucial, albeit initial, step in avoiding the errors of the ableist conflation. What if all health communication and medical professionals, all bioethicists and philosophers, and all politicians and global leaders made this distinction? What would it mean to carefully and consistently differentiate between such experiences of disability?

Following decades of work in disability studies and philosophy of disability, the following forms of disability should, at minimum, be distinguished:

congenital vs. noncongenital

healthy vs. unhealthy

visible vs. invisible

worldcreating vs. nonworldcreating

trauma-induced vs. nontrauma-induced

suffered vs. nonsuffered ${ }^{66}$

My hope is that by presenting these distinctions in such a broad and schematic way, it assists practitioners, in particular, to avoid many of the conceptual errors that seem so stubbornly entrenched across health communication. For example, cystic fibrosis is an unhealthy disability insofar as its ensuing inhibition of lung function creates significant and corporeally intrinsic difficulties and pains. On the contrary, the congenital "lack" of one's right hand, for example, is a healthy disability insofar as the primary difficulties one encounters will likely be due to the world being contingently crafted for people with two hands. If one has fibromyalgia or chronic pain or another sort of invisible disability, one must often pass as ablebodied. One's experiences will differ notably in certain respects from one with a visible disability like aphenotypical limb formation of an extremity. ${ }^{67}$

With respect to the fourth distinction, blindness is one example of a worldcreating disability. Life writings and memoirs report people experiencing blindness as a total, rich, and unique form of living in the world, not one invariably defined by lack in relation to the phenotypical "norm." ${ }^{68}$ If one is congenitally sighted and becomes blind through a traumatic event, one's experience will be expectedly different in instructive ways. It will take time to experience blindness as worldcreating and, depending upon a multitude of factors ranging from one's attitude, level of disability education, and societal context, one may or may not come to experience it in such a manner at all. One will likely never come to experience it 
thusly if one fails to shed the ableism into which we are all inculcated, albeit very differentially based upon our lived context. The noncongenital transition to the "disability" of blindness will invariably be experienced as a difficulty, but the resulting form of life is not thereby intrinsically negative. We often understand that the transition from state $\mathrm{X}$ to state $\mathrm{Y}$ may be unpleasant and suffered, despite the fact that neither state $\mathrm{X}$ or state $\mathrm{Y}$ is necessarily negative in and of itself (puberty, old age, peak fitness, etc.). Given the evidence available, this insight should be applied to cases of transition into states of disability as well.

Aging, depending upon the characteristics in question, can be experienced relatively gracefully or starkly. If accelerated or traumatic, one's experience of the "normal" processes in question can be fundamentally different from one who more slowly, knowingly, and lithely transitions into such experiences. It cannot be overstated how much one's understanding of the transitions of one's body bears upon one's judgment of that experience, whether traumatically induced or not. With respect to the final distinction, if one is obsessed with beauty and youth, one can, for example, even suffer aging, despite it being a natural and inevitable process. More gravely, if one lives in chronic pain, one experiences a form of disability significantly different than forms that are not necessarily concomitant with pain. That is to say, chronic pain names a form of disability that is almost by definition suffered. Having said this, what is stated here is admittedly insufficient with respect to the profound variance of experiences and understanding of the many forms of disability. I highlight here the utilization of these conceptual distinctions to help begin a renarration of the meaning of disability across health communication and practice.

Without disability education, we are curiously driven by fear in the interpretation of our fundamental corporeal variability. Simply that one experiences a given bodily variation or transition as an experience of suffering does not in and of itself mean that such an experience should automatically be judged as normatively negative by oneself, healthcare professionals, or ethicists. ${ }^{69}$ The semiosis of pain discussed above acts as a backdrop to definitively judge the value and fate of a life. When the distinctions above are made, the ableist conflation loses its preemptive and uncritical power, and the expansive breadth of lives worth living with disability comes to the fore. This transformation in the conceptualization of disability provides the first step for practitioners to address widespread disability stigma, discrimination, and oppression, including the inertia of "compulsory able-bodiedness," as Rober McRuer has aptly put it. ${ }^{70}$

\section{Health humanities and the legacies of ableism}

Rita Charon, among others, has argued for the import of medical/health humanities as an integral component of primary medical education. "Sickness calls forth stories," she writes, and it is because sickness is invariably conceived in terms of story and narrative that practitioners must learn to be adept interpreters. ${ }^{71}$ By linking certain forms of disability to pain, suffering, sickness, and death through an uncritical conceptualization of pain's semiosis, the lives and stories of people with disabilities are in too many cases considered to be pitiful, to be undesirable, or to constitute a life not worth living-even to the point of warranting or sanctioning death. It is incumbent upon those in health communication to listen to these stories better-to listen to the largest group of marginalized people. Yes, to reprise a fact that should be known by all, people with disabilities are the largest minority group in the world. ${ }^{72}$ 
Numerous disability communities and cultures, such as those in the Neurodiversity movement or in Deaf culture, provide uniquely rich and valuable ways of knowing and being. I have suggested that one of the more important ways for a practitioner to combat disability stigma is by decoupling disability from pain and actively educating patients and oneself about the multiplicity and richness of disability experiences and disability communities. Combating disability stigma means learning how to interpret ableism and the ableist conflation at work in stories of disability, in stories about fear or resilience in the face of illness, and in all storytelling and communication about the myriad experiences of bodily variation. Whether captured in the thought "I'd rather be dead than disabled," a thought still far too present in the atmosphere of patient-practitioner interactions, or captured in globally negative attitudes towards disability, healthcare professionals have a unique power and voice to support disability justice. I hope that by clarifying the structure of the ableist conflation, I have offered practitioners a tool to better address and help rectify the injustices and stigmas faced by people with disabilities.

\section{Notes}

1. Aeschylus, The Complete Aeschylus, 2 vols. (Oxford: Oxford University Press, 2011), 1: 351, verses $750-51$.

2. Anita Silvers, "Reconciling Equality to Difference: Caring (F)or Justice for People with Disabilities," Hypatia 10, no. 1 (1995): 37.

3. For example, Elizabeth Spelman speaks of the explicit intersection of "somatophobia" and misogyny in "Woman as Body: Ancient and Contemporary Views," Feminist Studies 8, no. 1 (1982): 109-31. I am thankful to Jennifer Scuro for this point.

4. S. Kay Toombs, The Meaning of Illness: A Phenomenological Account of the Different Perspectives of Physician and Patient (Boston: Kluwer Academic, 1992); "The Lived Experience of Disability," Human Studies 18, no. 1 (1995): 9-23.

5. Joel Michael Reynolds, "The Ableism of Quality of Life Judgments in Disorders of Consciousness: Who Bears Epistemic Responsibility?” American Journal of Bioethics Neuroscience 7, no. 1 (2015): 59-61.

6. Diane L. Smith, "Disparities in Patient-Physician Communication for Persons with a Disability from the 2006 Medical Expenditure Panel Survey (MEPS)," Disability and Health Journal 2, no. 4 (2009): 206-15.

7. In a forthcoming book-length work, I offer a phenomenological account of the ableist conflation's origin and its role across the history of philosophy.

8. There are numerous definitions of "ableism." For a helpful analysis and discussion of ableism more broadly, see Fiona Kumari Campbell, Contours of Ableism: The Production of Disability and Abledness (New York: Palgrave Macmillan, 2009).

9. Ashley Duggan, Ylisabyths Bradshaw, and Wayne Altman, "How Do I Ask About Your Disability? An Examination of Interpersonal Communication Processes between Medical Students and Patients with Disabilities," Journal of Health Communication 15, no. 3 (2010): 334-50; Li Iezzoni, "Make No Assumptions: Communication Between Persons with Disabilities and Clinicians," Assistive Technology 18, no. 2 (2006): 212-9.

10. Heather E. Canary, "Negotiating Dis/Ability in Families: Constructions and Contradictions," Journal of Applied Communication Research 36, no. 4 (2008): 437-58.

11. Tania De Bortoli et al., "Speech-Language Pathologists' Perceptions of Implementing Communication Intervention with Students with Multiple and Severe Disabilities," AAC: Augmentative \& Alternative Communication 30, no. 1 (2014): 55-70.

12. David S. Martins, "Compliance Rhetoric and the Impoverishment of Context," Communication Theory 15, no. 1 (2005): 59-77. There are well-documented disagreements over the language surrounding disability, but I will here follow person-first language (people with disabilities). 
13. Eva Feder Kittay and Licia Carlson, Cognitive Disability and Its Challenge to Moral Philosophy (Chichester, U.K.: Wiley-Blackwell, 2010).

14. Jackie Leach Scully, Disability Bioethics: Moral Bodies, Moral Difference (Lanham, MD: Rowman \& Littlefield, 2008), 3.

15. Elizabeth Barnes, The Minority Body (Oxford: Oxford University Press, 2016).

16. Tobin Siebers, "Disability in Theory: From Social Constructionism to the New Realism of the Body," American Literary History 13, no. 4 (2001): 737-54.

17. Karl Nunkoosing and Mark Haydon-Laurelut, "Intellectual Disability Trouble: Foucault and Goffman on 'Challenging Behaviour,'” in Disability and Social Theory: New Developments and Directions, ed. Dan Goodley, Bill Hughes, and Lennard Davis (New York: Palgrave Macmillan, 2012), 195-211.

18. Stacy Clifford Simplican, The Capacity Contract: Intellectual Disability and the Question of Citizenship (Minneapolis: University of Minnesota Press, 2015).

19. Lennard J. Davis, Enabling Acts: The Hidden Story of How the Americans with Disabilities Act Gave the Largest US Minority Its Rights (Boston: Beacon, 2015).

20. Joseph P. Shapiro, No Pity: People with Disabilities Forging a New Civil Rights Movement (New York: Three Rivers Press, 1993).

21. Ellen Samuels, "My Body, My Closet: Invisible Disability and the Limits of Coming Out," in The Disability Studies Reader, 4th ed., ed. Lennard J. Davis (London: Routledge, 2013), 316-53.

22. Margaret Price, "The Bodymind Problem and the Possibilities of Pain," Hypatia 30, no. 1 (2015): 268-84; Alyson Patsavas, "Recovering a Cripistemology of Pain: Leaky Bodies, Connective Tissue, and Feeling Discourse," Journal of Literary \& Cultural Disability Studies 8, no. 2 (2014): 203-18.

23. Michael Carl Gill, Already Doing It: Intellectual Disability and Sexual Agency (Minneapolis: University of Minnesota Press, 2015).

24. Shelley Tremain, Foucault and the Government of Disability (Ann Arbor: University of Michigan Press, 2005).

25. Joshua St. Pierre, "Distending Straight-Masculine Time: A Phenomenology of the Disabled Speaking Body," Hypatia 30, no. 1 (2015): 49-65.

26. Beth Ferri, "A Dialogue We've yet to Have: Race and Disability Studies," in The Myth of the Normal Curve, ed. Curt Dudley-Marling and Alex Gurn (New York: Peter Lang, 2010), 139-50.

27. Margaret Price, Mad at School: Rhetorics of Mental Disability and Academic Life (Ann Arbor: University of Michigan Press, 2011).

28. Beth A. Ferri and David J. Connor, "Talking (and Not Talking) About Race, Social Class and Dis/Ability: Working Margin to Margin," Race Ethnicity and Education 17, no. 4 (2014): 471-93.

29. Gregor Wolbring, "Expanding Ableism: Taking Down the Ghettoization of Impact of Disability Studies Scholars," Societies 2, no. 3 (2012): 75-83.

30. Jeffrey A. Brune and Daniel J. Wilson, Disability and Passing: Blurring the Lines of Identity (Philadelphia, PA: Temple University Press, 2013).

31. Douglas C. Baynton, "Disability and the Justification of Inequality in American History," in The New Disability History: American Perspectives, ed. Paul K. Longmore and Lauri Umansky (New York: New York University Press, 2001), 33-57; Kim E. Nielsen, A Disability History of the United States (Boston: Beacon, 2012); Henri-Jacques Stiker, A History of Disability (Ann Arbor: University of Michigan Press, 1999).

32. Rosemarie Garland-Thomson, Extraordinary Bodies: Figuring Physical Disability in American Culture and Literature (New York: Columbia University Press, 1997).

33. Tremain, Foucault and the Government of Disability; Miranda Fricker, Epistemic Injustice: Power and the Ethics of Knowing (Oxford: Oxford University Press, 2007).

34. Duggan, Bradshaw, and Altman, "How Do I Ask About Your Disability?" 335.

35. "The associated authors and medical education program define disability as a physical impairment that substantially limits one or more major life activities, and where mobility assistance for the disability includes a wheelchair, crutches, or an assistance dog." Ibid. 
36. Steven Pinker, “The Moral Imperative for Bioethics," Boston Globe, 1 August 2015 (emphasis added), https://www.bostonglobe.com/opinion/2015/07/31/the-moral-imperative-for-bi oethics/JmEkoyzlTAu9oQV76JrK9N/story.html. This article was then reported at multiple bioethics news outlets, including BioEdge.

37. Humanity+, "Transhumanist Faq," http://humanityplus.org/philosophy/transhumanist-faq/. On the relation of trans- and posthumanism to disability and disability studies, see Melinda Hall, The Bioethics of Enhancement: Transhumanism, Disability, and Biopolitics (Lanham, MD: Rowman \& Littlefield, 2016); Alison Kafer, Feminist, Queer, Crip (Bloomington: Indiana University Press, 2013); Scott DeShong, "On (Post)Human (Dis)Ability," Subjectivity: International Journal of Critical Psychology 5, no. 3 (2012): 265-75.

38. My thanks to Jennifer Scuro for this insight.

39. Pinker, "The Moral Imperative for Bioethics," (emphasis added).

40. At multiple points in this piece, I speak of "pain and suffering," and I do so only because arguments to distinguish between the two (and the multiple forms of each) would require an essay (or more) of their own. I ask that the reader thus take this phrase with a grain of analytic salt.

41. Marilee Strong, A Bright Red Scream: Self-Mutilation and the Language of Pain (New York: Viking, 1998); Romana Byrne, Aesthetic Sexuality: A Literary History of Sadomasochism (New York: Bloomsbury, 2013).

42. Eva Feder Kittay, Love's Labor: Essays on Women, Equality, and Dependency (London: Routledge, 1999); Silvers, "Reconciling Equality to Difference"; Rosemarie Garland-Thomson, "Staring Back: Self-Representations of Disabled Performance Artists," American Quarterly 52, no. 2 (2000): 334-8.

43. The question of what constitutes a "harm" in relation to given cases of disability is itself a major point of debate in philosophy of disability. Barnes's The Minority Body provides a helpful overview. See also Joel Michael Reynolds, "Toward a Critical Theory of Harm: Ableism, Normativity, and Transability (BIID)," APA Newsletter on Philosophy and Medicine 16, no. 1 (2016): 37-45.

44. Kafer, Feminist, Queer, Crip; Mark Sherry, Disability Hate Crimes: Does Anyone Really Hate Disabled People? (Burlington, VT: Ashgate, 2010). Inspiration porn refers to instances in which people with disabilities are viewed as "inspirational" only by virtue of overcoming their disability.

45. Adam Milani, "Better Off Dead Than Disabled? Should Courts Recognize a 'Wrongful Living' Cause of Action When Doctors Fail to Honor Patients' Advance Directives?" Washington and Lee Law Review 54, no. 1 (1997): 149-228.

46. Recall that disability is left underdefined in the broadest formulation of the ableist conflation. It is not immediately clear whether needing glasses or intermittent depression constitutes disability, while few, if any, would argue that paraplegia or cystic fibrosis does not. This ambiguity is precisely part of the issue(s) at stake here.

47. Paul K. Longmore, Telethons: Spectacle, Disability, and the Business of Charity (Oxford: Oxford University Press, 2015).

48. See note 43 above.

49. Buck V. Bell (Carrie Buck V. James Hendren Bell, Superintendent of State Colony for Epileptics and Feeble Minded), Oliver Wendell Holmes Jr. (1927).

50. Rosemarie Garland-Thomson, "Human Biodiversity Conservation: A Consensual Ethical Principle," The American Journal of Bioethics 15, no. 6 (2015): 13-15.

51. Fyodor Dostoyevsky, The Brothers Karamazov: A Novel in Four Parts with Epilogue, trans. Richard Pevear and Larissa Volokhonsky (New York: Farrar, Straus and Giroux, 2002), 238.

52. International Association for the Study of Pain, "IASP Taxonomy," http://www.iasp-pain. org/Taxonomy. The concept of pain has a long and complex history I cannot address here; there are multiple, large literatures that discuss it ranging from palliative care to internecine debates in philosophy of mind. See Roselyne Rey, The History of Pain (Cambridge, MA: Harvard University Press, 1995); Keith Wailoo, Pain: A Political History (Baltimore, MD: Johns Hopkins University Press, 2014). 
53. See Serge Marchand, The Phenomenon of Pain, International Association for the Study of Pain (Seattle, WA: IASP Press, 2012); Patrick D. Wall, Pain: The Science of Suffering (New York: Columbia University Press, 2000); Ronald Melzack and Patrick D. Wall, The Challenge of Pain, rev. ed. (New York: Penguin, 1988); Murat Aydede, Pain: New Essays on Its Nature and the Methodology of Its Study (Cambridge, MA: MIT Press, 2005); Colin Klein, What the Body Commands: The Imperative Theory of Pain (Cambridge, MA: MIT Press, 2015).

54. David Cecil Sinclair, Cutaneous Sensation (Oxford: Oxford University Press, 1967), 7-8. See Joel Michael Reynolds, "Feeding Upon Death: Pain, Possibility, and Transformation in S. Kay Toombs and Kafka’s the Vulture," Jahrbuch Literatur und Medizin 6 (2014).

55. Eugen Baer, Medical Semiotics (Lanham, MD: University Press of America, 1988); John F. Burnum, "Medical Diagnosis through Semiotics: Giving Meaning to the Sign," Annals of Internal Medicine 119, no. 9 (1993): 939-43.

56. See "semiosis, n.", "semiotic, adj. and n.", and "sign, n."-whose oldest etymological roots

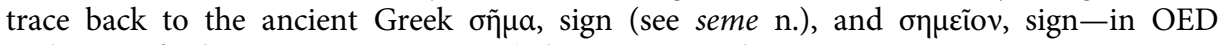
Online: Oxford University Press, 2014), http://www.oed.com/.

57. Charles S. Peirce, The Philosophy of Peirce: Selected Writings (London: K. Paul, Trench, 1940), 99.

58. This is true as well as for Frege Gottlob, "Sense and Reference," The Philosophical Review 57, no. 3 (1948): 209-30.

59. Martin Heidegger notes that while the term "sign" can cover many different kinds of signs, the sign can also be "formalized as a universal kind of relation" (Being and Time, trans. Joan Stambaugh, rev. Dennis J. Schmidt [Albany: State University of New York Press, 2010], 76). On the role of formal indication for Heidegger, see Ryan Streeter, "Heidegger's Formal Indication: A Question of Method in Being and Time," Man and World 30, no. 4 (1997): 413-30.

60. As Andrew J. Mitchell writes, "Pain indeed separates and rends us, but only in order to grant relation. For this reason Heidegger will speak of a 'contrary essence' of pain.... Pain is a wound of relation and insofar as the tear of pain joins us to the world, this pain is always a shared pain" (“Entering the World of Pain: Heidegger," Telos 2010, no. 150 [2010]: 86).

61. Claire Sibonney, “Americans Would Rather Be Dead Than Disabled: Poll," Reuters, 11 July 2008, http://www.reuters.com/article/us-disability-idUSN7B32025920080711.

62. Lennard J. Davis, Enforcing Normalcy: Disability, Deafness, and the Body (New York: Verso, 1995).

63. This assumes, of course, that pain is narrowly interpreted as solely negative. Insofar as negative experiences are not seen as part of a dialectic with positive experiences, they will be considered intrinsically negative-a type of experience one wants to avoid in principle. As is well documented across various domains of pain research, there are a number of practices where people actively seek out pain and in which pain is often described in positive terms. However, there is significant disagreement whether this means that pain can in and of itself be experienced positively or if second-order intentions and habits instead serve to alter or even mask the fundamental negativity of such experience. This is further troubled by the way in which pain is simultaneously singularizing and universalizing. Only "I" have my pain, a pain that "we" all presumably can experience. On the latter point, see David M. Peña-Guzmán, "Pathetic Normativity: Merleau Ponty and Canguilhem's Theory of Norms," Chiasmi International 15 (2013): 361-84.

64. Susan Wendell, "Unhealthy Disabled: Treating Chronic Illnesses as Disabilities," Hypatia 16, no. 4 (2001): 17-33. See also Donna Reeve, "Psycho-Emotional Disablism and Internalised Oppression," in Disabling Barriers-Enabling Environments, 3rd ed., ed. John Swain et al. (Thousand Oaks, CA: Sage, 2014), 92-98.

65. John T. Lysaker and Paul H. Lysaker, Schizophrenia and the Fate of the Self (Oxford: Oxford University Press, 2008). I put "mental illnesses"' in quotation marks to signal the fact that this is a problematic category for those aligned with the Neurodiversity and Mad Pride movements. 
66. This list is, of course, a heuristic and an incomplete one at that. In various ways and with varying terminology, these distinctions have been addressed by disability studies scholars and activists for years. See Lennard J. Davis, The Disability Studies Reader, 4th ed. (London: Routledge, 2013).

67. Or take dyslexia, stuttering, or any number of other forms of disability whose "visibility" is liminal, depending upon context.

68. Joel Michael Reynolds, "Merleau-Ponty's Aveugle and the Phenomenology of Non-Normate Embodiment," Chiasmi International 18 (Forthcoming); Georgina Kleege, Sight Unseen (New Haven, CT: Yale University Press, 1999); John Hull, On Sight and Insight: A Journey into the World of Blindness (London: Oneworld, 1997). As Hull makes clear, whether one experiences noncongenital blindness as a lack is largely in relation to the extent to which one successfully transitions into that new form of experience.

69. Note that this formulation can be reversed. Among other reasons, this is why there is such a need for further empirical and critical research on the relations between well-being, bodily difference, and bodily transitions.

70. Robert McRuer, Crip Theory: Cultural Signs of Queerness and Disability (New York: New York University Press, 2006).

71. Rita Charon, Narrative Medicine: Honoring the Stories of Illness (Oxford: Oxford University Press, 2006), 203.

72. Lennard J. Davis, Enabling Acts.

\section{Acknowledgements}

For feedback on previous versions of this paper, I am grateful to Carmen C. Gomen, Nicole Piemonte, and Jennifer Scuro. Various sections of this paper have been presented at the Society for Disability Studies, the Bioethics: Preparing for the Unknown conference at Western Michigan University, the Undoing Health: States of Body \& Mind interdisciplinary graduate conference at Indiana University, and the Emory Philosophy Forum. I am grateful to each audience for insightful and constructive feedback.

\section{ORCID}

Joel Michael Reynolds (D) http://orcid.org/0000-0002-9640-5082 